\title{
A FLORISTIC SURVEY OF A UNIQUE LOWLAND RAIN FOREST IN MORAELLA IN THE KNUCKLES VALLEY, SRI LANKA
}

\author{
W. W. M. A. B. Medawatte ${ }^{1,2^{*}}$, E. M. B. Ekanayake $^{1}$, K. U. Tennakoon ${ }^{3}$, C.V.S Gunatilleke ${ }^{1}$ and \\ I. A. U. N. Gunatilleke ${ }^{1}$ \\ ${ }^{1}$ Department of Botany, University of Peradeniya, Peradeniya, Sri Lanka \\ ${ }^{2}$ Postgraduate Institute of Science, University of Peradeniya, Peradeniya \\ ${ }^{3}$ Department of Biology, University of Brunei, Gadong BE 1410, Brunei Darussalam \\ Accepted 01 June 2011
}

\begin{abstract}
The luxuriant natural forests of the western lower slopes and valleys of the Knuckles range have been heavily deforested since the mid $-19^{\text {th }}$ century for conversion to coffee and tea plantations. Consequently, only scant floristic and ecological signatures of the original vegetation are still found, notably as scattered enclaves along stream reservations. Recently, an isolated forest fragment at 500-700 m amsl, not recorded previously, was located in Moraella in the valley of Kukul Oya (stream) in the south western foothills of Knuckles range. A vegetation survey of this forest recorded a total of 204 flowering plant species in 70 families. Eighty-nine (44\%) of the species are endemic to Sri Lanka, while 39 (20\%) are nationally threatened. Among the 148 tree, treelet and shrub species identified, 74 (50\%) have not been recorded during previous floral surveys of the Knuckles forest reserve, while 115 (78\%) are common to the lowland rain forests of south-western Sri Lanka. The existence of a similar forest fragment located near Kosgama on the banks of Hulu Ganga (river), suggests that they represent remnants of a once extensive lowland rain forest formation. These forest fragments likely mark the north-eastern-most limits of distribution of lowland rain forests in Sri Lanka and warrant urgent conservation as biodiversity refugia. They may be the last vestiges of an almost disappearing lowland rain forest type in the Knuckles range.
\end{abstract}

Key words: Sri Lankan flora, Dipterocarpaceae, 'Dumbara Mitiyawatha', refugia

\section{INTRODUCTION}

The Knuckles range (KR), in the Kandy and Matale districts is a northern outlier of the central highlands in Sri Lanka; its peaks are frequently laden with mist and hence it is locally known as 'Dumbara Kanduwetiya'. It is also known locally as 'Batadandu Kanduwetiya' for the prevalance of bamboo-dominated forests (Anon, 1998). The south-western (SW) and southern sides of the KR is separated from the main central highlands by the valley of the Mahaweli river (de Rosayro, 1958), also bordering its eastern lowlands. The valley and the lower slopes on the left bank of the river is commonly known as the 'Dumbara Mitiyawatha' (meaning 'mist laden valley'; Cooray, 1984). The name Knuckles, was given to it by the early British surveyors, as its main massif (Fig. 1) resembles a clenched fist (Bambaradeniya and Ekanayake, 2003). The Knuckles forest reserve (KFR) encompasses an area of $180 \mathrm{~km}^{2}$ within the altitudinal range of $115-1905 \mathrm{~m}$ and comprises several hill ranges. The main KR, lying approximately $50 \mathrm{~km}$ from Bowatanna reservoir of the Amban Ganga (north-western end; Ganga = river) to Randenigala reservoir of Mahaweli Ganga (south-eastern end), has four major lateral ranges descending towards the north-eastern (NE) (Rambukoluwa range), eastern (Kalupahana range and Dumbanagala range) and SW (Hunnasgiriya range) lowlands (Fig. 2).

Due to its geographic location, physiographic variability and altitudinal range, the KR exhibits a variety of climatic regimes ranging from wet on the SW and western slopes and valleys, to seasonally dry on the eastern and NE slopes (Mueller Dombois, 1968; Domros, 1974; Sri Bharathie, 1993). The whole region receives rain mainly from the NE monsoons that prevail from December to February. The wetter western slopes (Rattota, Elkaduwa, Wattegama, Panwila, Hatale, Madulkele, Arattana, Baddegama and Werapitiya) receive rain from both the SW (May-September) and NE monsoons (DecemberFebruary) and the highland regions are very wet, with mist and strong winds during the monsoons (National Atlas, 1988, Mueller Dombois, 1968; Domros, 1974). This area belongs to the WM3b

*Corresponding author's email: amedawatte@yahoo.com 


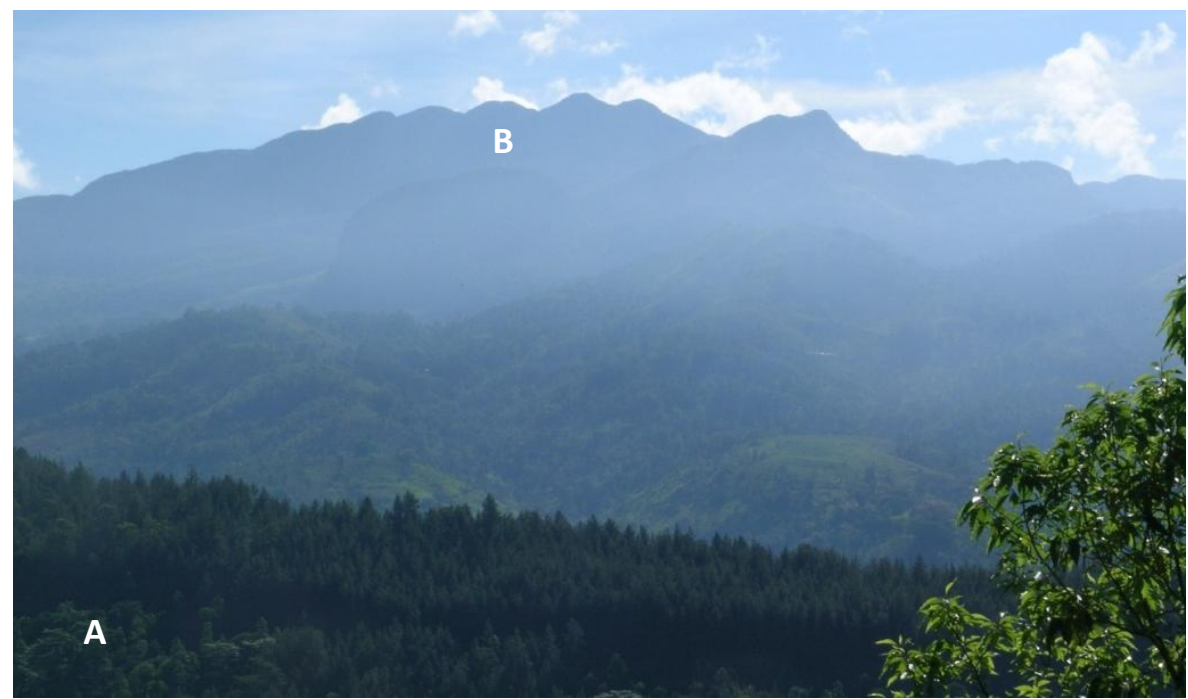

Figure 1. Part of Moraella forest (A) on the SW foothills of the Knuckles Range (B) in the background.

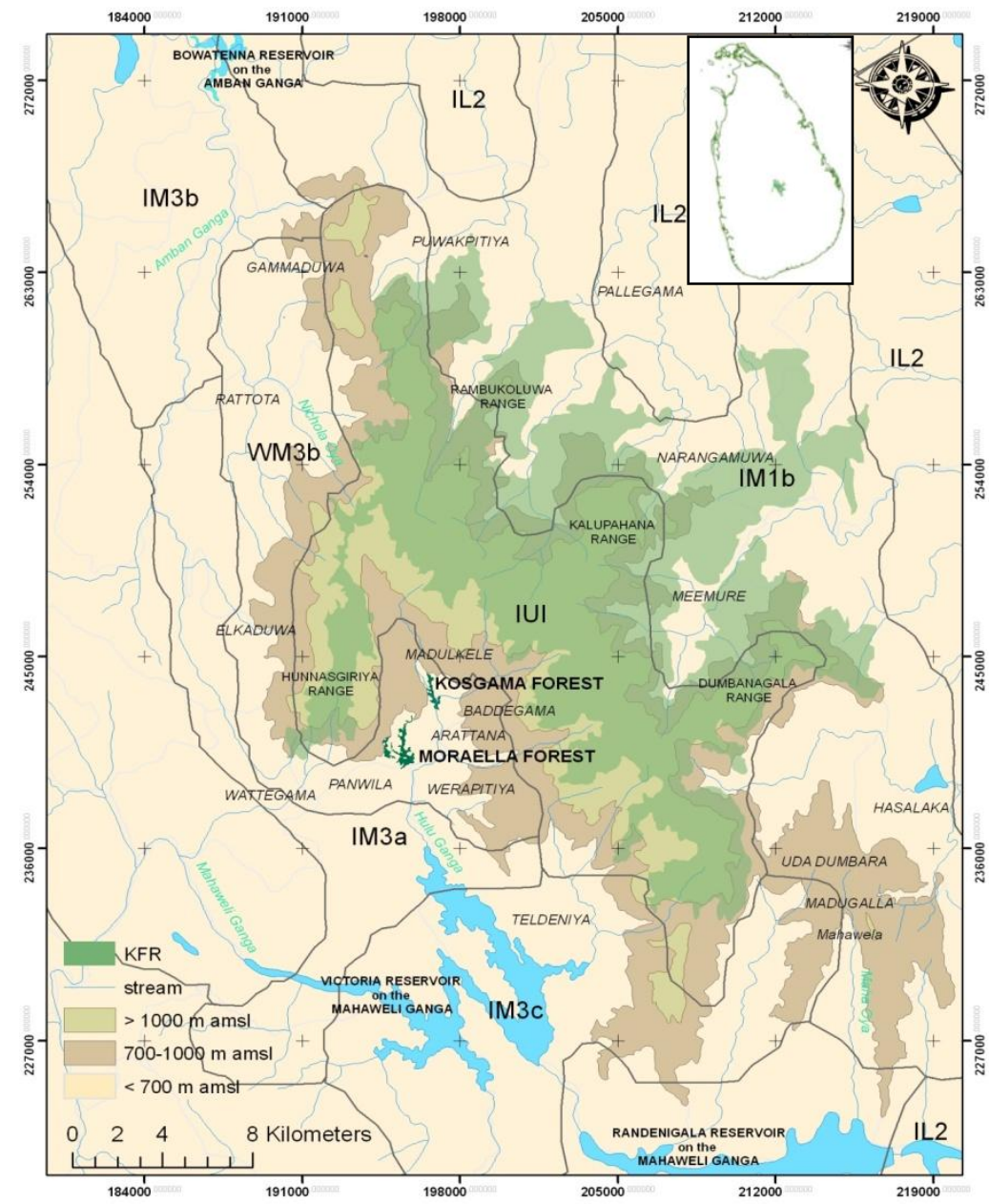

Figure 2. Locations of Moraella and Kosgama forest fragments (dark green) and Knuckles forest reserve (KFR) in the Knuckles Range, Sri Lanka. (WM3b = Wet Mid country 3b; IM1b, IM3a, IM3b, IM3c = Intermediate Mid country 1b, 3a, 3b and 3c; IL2 = Intermediate Low country 2, IU1= Intermediate Upcountry 1) (Co-ordinates based on Sri Lanka Datum 1999, National Atlas, 1988). 
Agro-ecological region of Sri Lanka (Fig. 2, Panabokke, 1996). The higher ridges of the KR act as an orographic barrier. They ensure that relatively little rain from the SW monsoon falls on its eastern and NE slopes (Puwakpitiya, Illukumbura, Pallegama, Narangamuwa, Meemure, Hasalaka, Kalugala and Madugalle), that are influenced by strong desiccating föhn winds, known locally as 'Kachchan' (Legg, 1995; Sri Bharathie, 1993). This high climatic variation in the KR has resulted in a diversity of forest types representative of most forest types in the island (Abeywickrama, 1964). Its distinctive floristic composition and phyto geography has already resulted in the demarcation of the KR as a separate floristic region owing to the high level of infra-generic plant endemism, and the presence of unique Deccan-Gondwanan relicts (Ashton and Gunatilleke, 1987). De Rosayro (1958) recognized three major vegetation formations, viz., Lowland Tropical Wet Semi- evergreen Forest, Sub-montane Tropical Wet Semi-evergreen Forest and Montane Tropical Wet Evergreen Forest, based on aerial photointerpretation correlated with extensive field enumerations. He further classified them into 16 sub-divisions of vegetation types within the KR. More recently, Bambaradeniya and Ekanayake (2003) reported eight major vegetation types in the KFR. The latter authors refer to only the major vegetation types, while the former gives sub-types within some of the major vegetation types (Table 1). However, neither of the publications reports a Tropical Lowland Rain Forest (TLRF) type in the KR, i.e. the typical forest type found in the SW lowlands of Sri Lanka.

The major vegetation type in the foothills below $900 \mathrm{~m}$ of the KR located on the drier northern and NE slopes has been classified as Tropical Lowland Wet Semi-Evergreen Forest by de Rosayro (1958). This forest type

Table 1. Vegetation types in the Knuckles forest reserve described by previous authors.

1. Lowland tropical wet semi-evergreen forest $(<700 \mathrm{~m})$
A Tropical wet semi-evergreen Forest
B Low jungle
C Riparian forest

2. Sub-montane semi-evergreen forest (900-1500 m)
A Sub-montane semi-evergreen forest- Dry faciation
B Sub-montane semi-evergreen forest- Wet faciation
C Sub-montane grassland (patana)
D Sub-montane savannah
E Sub-montane scrub forest

3. Montane tropical wet evergreen forest (>1500 m)
A Montane tropical wet evergreen forest- dry faciation
B Montane tropical wet evergreen forest- wet faciation
C Low forest- montane thicket
D Elfin forest
E Pigmy forest
F Montane forest
G Bamboo brake
F Palm brake

1. Semi-evergreen forest

2. Riverine forest

3. Sub-montane forest

$-$

4. Patana grassland

5. Savannah

6. Scrublands

7. Montane forest

8. Rock outcrop forest 
corresponds to the Semi-Evergreen Forest of Bambaradeniya and Ekanayake (2003), and is confined to the eastern lowlands around Meemure, Pallegama and Illukkumbura. Legg (1995) reported that this forest has lower species diversity than the lowland rain forests and that some plants such as Drypetes sp. found in the semi-evergreen forests are more typical of the drier parts of the island. However, Abeywickrama (1964) reported that many lowland rain forest species are present here, with the exception of species belonging to the family Dipterocarpaceae. One of the most detailed and comprehensive studies in recent times carried out by Legg (1995), developed a geographic information system (GIS) for conservation planning and management, using satellite remote sensing techniques. This study included topographic, forest, climatic and administrative information, but this too, did not recognize any natural forest formations in the wetter western and SW lower slopes (300-900 m) of the KR.

\section{OBJECTIVES}

The present investigation was particularly focused on establishing what the natural forest type would have been on the western lower slopes and valleys of the KR prior to the introduction of coffee and tea plantations since the mid- $19^{\text {th }}$ century by the British planters (Legg, 1995). The earliest recorded large scale forest clearence in this region had occurred around 1840 for coffee planting in what were then known as the 'coffee districts' of Knuckles, Rangala, Kelebokka, 'Doombara' etc. (Ferguson, 1859).

The objectives of this investigation were twofold: (i) to carry out a floristic inventory of the remnant forest patches on the lower western foothills of the KR and list the species therein; (ii) to determine to what extent the flora of this forest resemble that of the lowland wet evergreen forests or rain forests of SW Sri Lanka and the lowland semi-evergreen and lower montane forests described previously from the KR.

\section{MATERIALS AND METHODS}

\section{Identification of remnant forest patches}

The existence of remnant natural forest patches was determined through a study of the relevant 1:50,000 topographic maps of the western slopes of the KR, followed by field reconnaissance surveys for verification.

\section{Study area}

Reconnaissance surveys of the western and $\mathrm{SW}$ slopes of the KR revealed the presence of two forest remnants, about $2 \mathrm{~km}$ apart. Both forests are situated within the 'Patha' (lower) and 'Meda' (mid-) Dumbara Administrative Divisions in the western and SW valley of the KR. These fragments are located outside the present boundary of the KFR within the Panwila Forest Beat and administered by the Kandy District Secretariat. The smaller of the two, located at $7^{\circ} 23^{\prime} 06.30^{\prime \prime}-7^{\circ} 24^{\prime} 04.60^{\prime \prime} \mathrm{N}, 80^{\circ} 44^{\prime}$ $29.96 "-80^{\circ} 45^{\prime} 03.45^{\prime \prime} \mathrm{E}$, is 48 ha in extent and between $500-650 \mathrm{~m}$ amsl, and on the lower slopes of the Hulu Ganga, in close proximity to Kosgama village. The larger is about 95 ha in extent, at $7^{\circ} 21^{\prime} 37.68^{\prime \prime}-7^{\circ} 22^{\prime} 46.02^{\prime \prime} \mathrm{N}, 80^{\circ}$ 43 '20.64" - $80^{\circ} 44^{\prime} 12.20^{\prime \prime}$ E, also between 500$700 \mathrm{~m}$ amsl on the banks of the Kukul Oya (Oya=stream), one of the -tributaries of Hulu Ganga. This latter area is known as Moraella (or Morahela) and located SW of Arattana village and south-east of Hatale tea plantation. The larger forest fragment, hereafter referred to as the Moraella forest, was selected as our study area. This lies on the SW limits of the Knuckles floristic region of Sri Lanka (Ashton and Gunatilleke, 1987). The fragment selected was also mapped using Arc GIS 9.2 (ESRI, USA) software (Fig. 3).

\section{Climate of study area}

The study site lies within an area of mean annual rainfall $>2500 \mathrm{~mm}$ (Fig. 4; National Atlas 1988). The mean monthly rainfall for the Moraella forest area was determined from the data maintained at the Madulkele Tea Factory (from 1997-2006) located approximately $2 \mathrm{~km}$ away.

\section{Floristic survey}

A floristic inventory of the Moraella forest was made based on several reconnaissance surveys carried out during 2006-2010. Representative samples of its plant species that could not be identified in the field were collected, preserved and herbarium specimens prepared for identification at the National Herbarium, Peradeniya. As far as possible, taxa in all angiosperm life form groups [trees, treelets, shrubs, herbs, epiphytes (only Orchidaceae and Loranthaceae) and climbers] were inventoried, and a list was prepared. Among the plant species identified, the endemic species were determined using 'A Checklist of the Flowering Plants of Sri Lanka' (Senaratne, 2001), and the national and/or global 
conservation status of species was determined using the IUCN Red List, 2007.

The checklist of flora compiled for the Moraella forest was then compared with published floral lists of tree, treelet and shrub species for the tropical lowland rain forests (TLRF) Sinharaja, Kottawa, Hinidumkanda,
Kanneliya and Gilimale forests (all in the southwestern lowlands) and also for lowland forests in the KR (Gunatilleke et al., 2004a; Gunatilleke and Gunatilleke, 1991; Bambaradeniya and Ekanayaka, 2003; de Rosayro, 1958; Anon., 1997b).

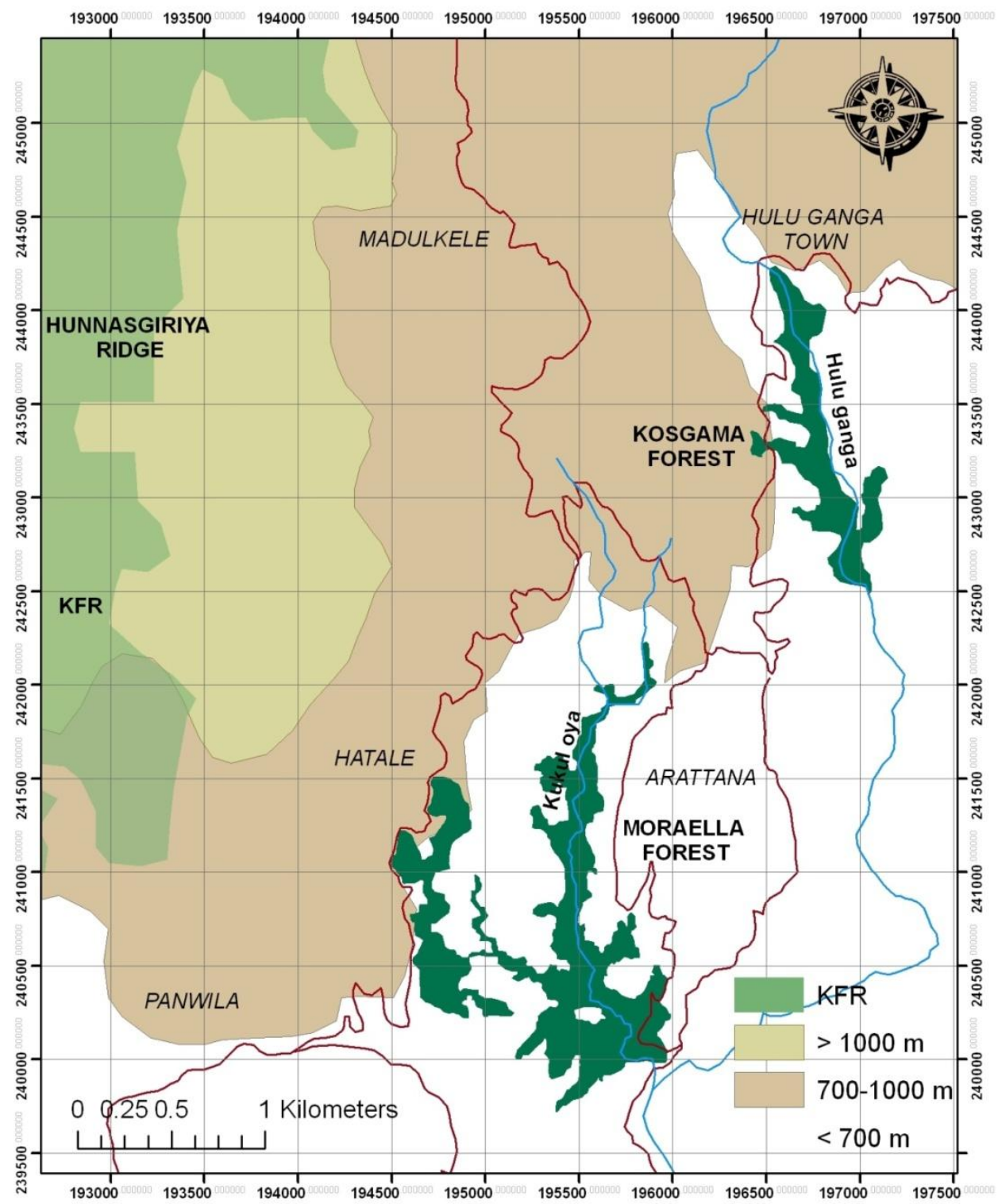

Figure 3. Locations of the lower Dumbara rain forest (Moraella and Kosgama forest fragments) in the Knuckles Range, in relation to Hulu Ganga and one of its tributaries, the Kukul Oya (Coordinates based on Sri Lanka Datum 1999, National Atlas, 1988). 


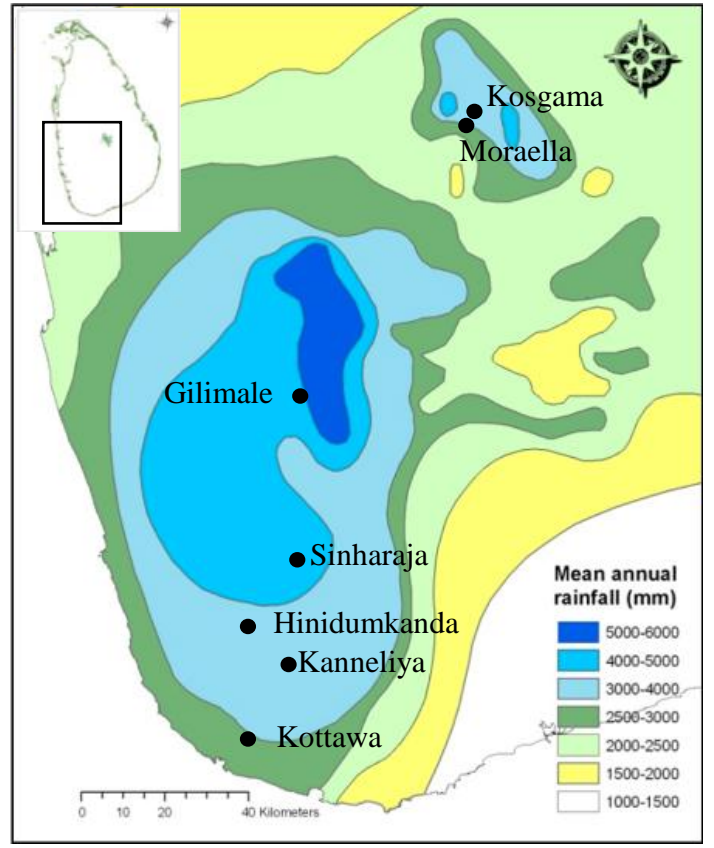

Figure 4. Map of Sri Lanka (in part) showing the rainfall ranges of Moraella and Kosgama forests in the Kunckles Range and in Sinharaja, Kottawa, Hinidumkanda, Kanneliya and Gilimale forests in the South West (Source: National Atlas of Sri Lanka, 1988).

\section{RESULTS AND DISCUSSION}

The mean annual rainfall in the vicinity of the Moraella forest is $>2500 \mathrm{~mm}$, which is comparable to that of the TLRF areas in SW Sri
Lanka (Fig. 4). However, Sinharaja and Gilimale forest areas receive $4000-5000 \mathrm{~mm}$ and even $>6000 \mathrm{~mm}$ in very wet years (Domros, 1974; National Atlas, 1988). In the general area of Madulkele close to the Moraella forest, a mean monthly rainfall around $100 \mathrm{~mm}$ (Fig. 5) has been recorded even during the least wet months, as also recorded in rain forests like Sinharaja.

The vegetation surveys conducted in the Moraella forest study site recorded a total of 204 angiosperm species, belonging to 70 families (Appendix 1). Among these were 124 tree-, 9 treelet-, 15 shrub-, 36 each of herbaceous and epiphytic species, and one graminoid species. The site is rich in orchids, represented by 14 epiphytic and 5 terrestrial species. There were 19 species of climbers as well. Among the plant species identified in Moraella forest, 89 (44\%) are endemic to Sri Lanka (Table 2). Based on the IUCN Red List categories, among the species identified, $39(20 \%)$ are assessed as nationally threatened; 18 of them are globally threatened. Seven species (4\%) are nationally near threatened (Table 2, Appendix 1).

Among the 148 tree, treelet and shrub species recorded in this study, $74(50 \%)$ have not been reported in previous surveys of the KFR (Bambaradeniya and Ekanayake, 2003; de Rosayro, 1958 and Anon., 1997b). On the other hand, the majority of the species, viz., 115 (78\%) of the tree, treelet and shrub species in the present study, have also been recorded from the TLRF of SW Sri Lanka (Anon., 1997b; Gunatilleke et al., 2004a \& b and Gunatilleke and Gunatilleke, 1991) (Appendix 1).

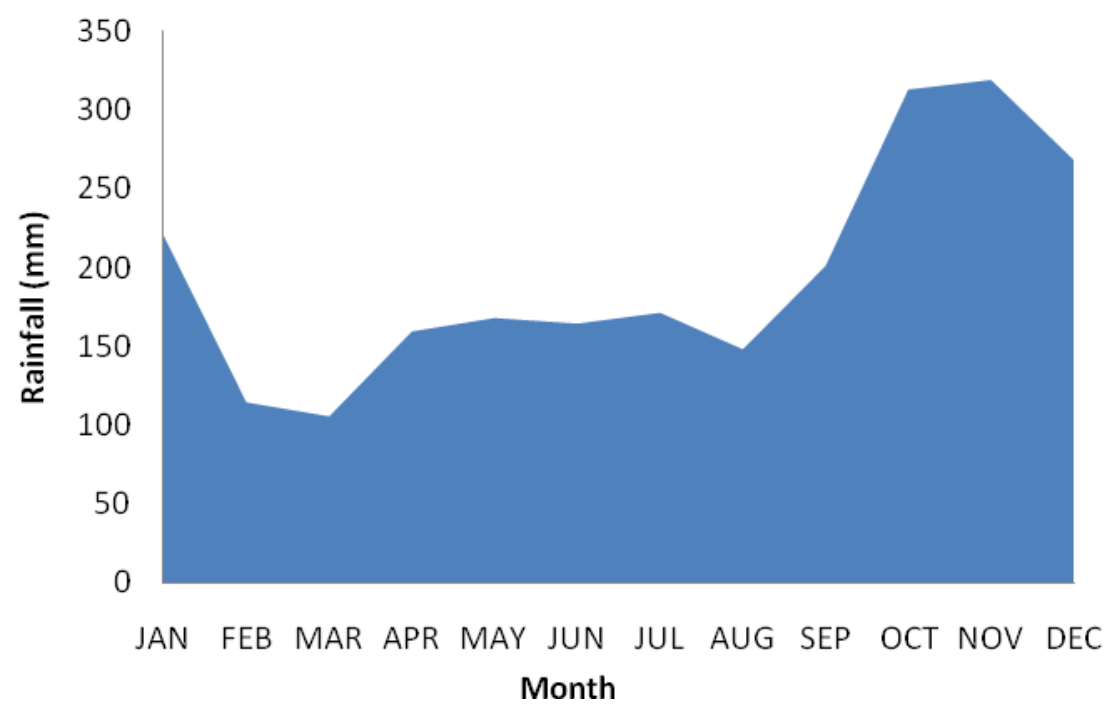

Figure 5. Mean monthly rainfall from 1997 to 2006 compiled from data recorded at Madulkele tea factory, $(850 \mathrm{~m}$ amsl), which is situated $\sim 2 \mathrm{~km}$ north of the Moraella forest. 
Table 2. (A) Proportions of flowering plant species in different distributional range categories in Moraella forest and (B) IUCN Red List categories (IUCN Red List, 2007), where percentages were calculated based on the total number of identified species ( $n=197$ species).

(A)

\begin{tabular}{lcc}
\hline Taxa in different categories & Number of plant taxa & \% of recorded species \\
\hline Endemic species & 89 & 44 \\
Non-endemic (indigenous) species & 105 & 51 \\
Introduced \& naturalized species & 3 & 1 \\
Identified to genus level only & 7 & 4 \\
\hline Total & 204 & 100 \\
\hline
\end{tabular}

(B)

\begin{tabular}{|c|c|c|c|c|}
\hline \multirow[b]{2}{*}{ IUCN Red List Categories } & \multicolumn{2}{|c|}{$\begin{array}{c}\text { National Threat Status } \\
\text { (including Global) }\end{array}$} & \multicolumn{2}{|c|}{$\begin{array}{c}\text { Threat } \\
\text { Status Globally }\end{array}$} \\
\hline & $\begin{array}{c}\begin{array}{c}\text { Number } \\
\text { of plant } \\
\text { spp. }\end{array} \\
\end{array}$ & $\begin{array}{c}\text { \% of total } \\
\text { identified to } \\
\text { spp. }\end{array}$ & $\begin{array}{c}\text { Number } \\
\text { of plant } \\
\text { spp. }\end{array}$ & $\begin{array}{c}\text { \% of total } \\
\text { identified to } \\
\text { spp. }\end{array}$ \\
\hline $\begin{array}{l}\text { Critically } \\
\text { endangered }\end{array}$ & 04 & 02 & 02 & 1 \\
\hline Endangered & 05 & 03 & 01 & 1 \\
\hline Vulnerable & 30 & 15 & 15 & 8 \\
\hline Near threatened & 07 & 04 & 00 & 0 \\
\hline Total & 46 & 24 & 18 & 10 \\
\hline
\end{tabular}

The Dipterocarpaceae is abundant in the vegetation of the Moraella forest, and is represented by Dipterocarpus zeylanicus Thw., Shorea dyeri Thw. ex Trimen and Vateria copallifera (Retz.) Alston (Fig. 6). These species have not been recorded in the KFR in previous vegetation surveys, although sporadic herbarium collections of $D$. zeylanicus and $S$. dyeri have been made from this region (Ashton, 1980; Kostermans, 1992). Additionally, the three species referred to above co-exist with other plant species characteristic of TLRF of SW Sri Lanka. For these reasons, Moraella forest can be considered as a TLRF or a dipterocarp forest (Greller et al., 1993). The local abundance of $D$. zeylanicus and $V$. copallifera in this forest fragment indicates the riparian nature of the forest dominated by a Dipterocarpus community (de Rosayro, 1950) as seen in the foothills of Hinidumkanda (Gunatilleke and Gunatilleke, 1984) and in alluvial flats in Sinharaja (Merritt and Ranatunga, 1959). Isolated individuals of these dipterocarp species have been observed in Nichola Oya (near Horagolla and Halgolla) and the general area of Rattota (pers. obs.). Interestingly another riverine forest with a population of an endemic dipterocarp, Stemonoporus acuminatus has been reported in Mahawela on the banks of Maha Oya within the Victoria-Randenigala-Rantembe Sanctuary at the south-eastern end of the KR (Anon., 1997a).

A striking floristic feature of the Moraella forest however, is the absence of any members of the dipterocarp genus Doona, which is a major characteristic element of the MesuaDoona community that dominates the TLRF of SW Sri Lanka (Gunatilleke et al., 2004a; Gunatilleke et al., 2006). Instead, Shorea dyeri of Dipterocarpaceae is locally abundant in alluvial sites above the stream in Moraella. We speculate that this area of the KR, despite receiving a high mean annual rainfall experiences a minimal, but more prolonged, seasonality with lower rainfall during one to few months. The ever wet SW Sri Lanka, on the other hand, may experience more humid conditions during the comparable months. This less than ever wet condition in the KR 

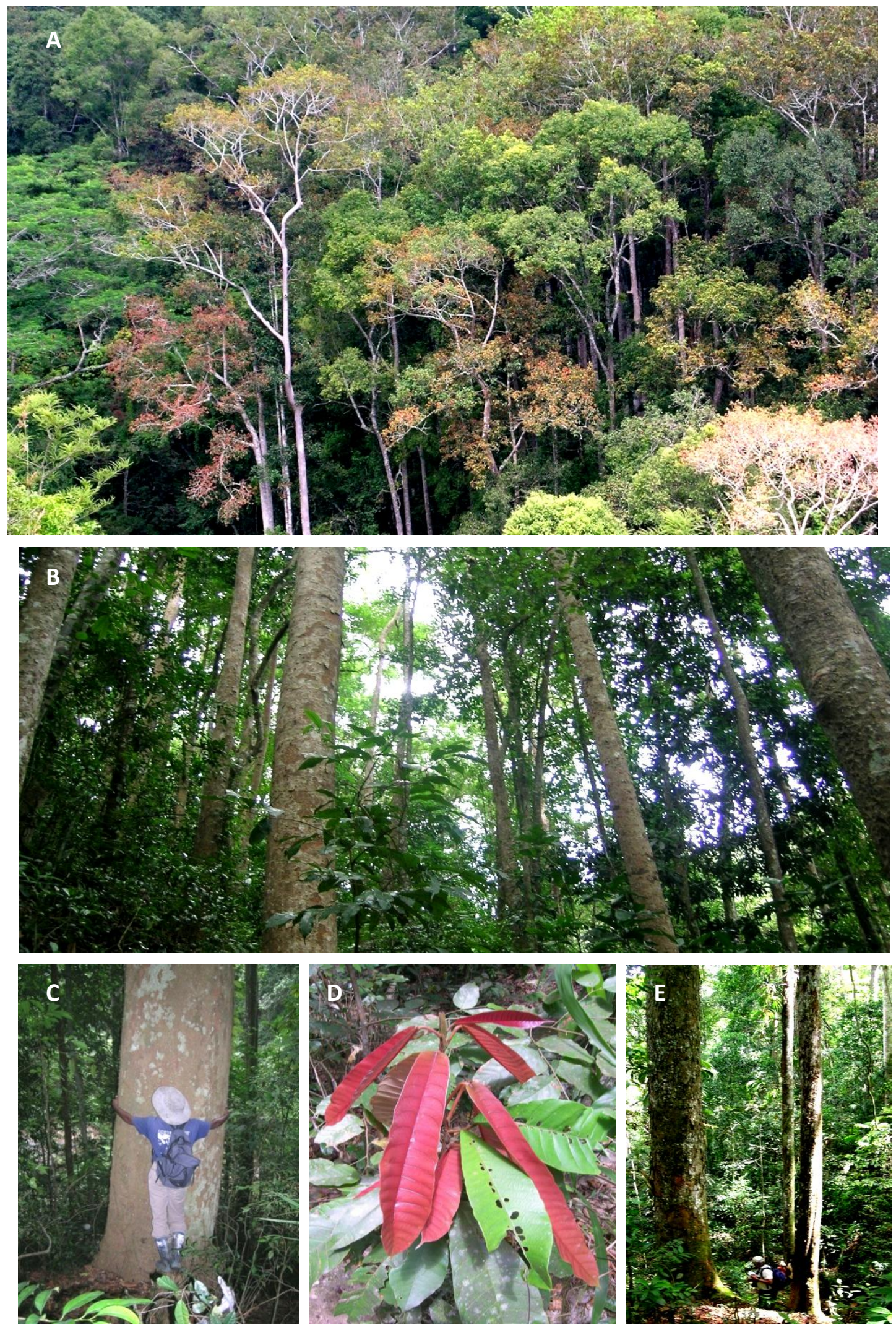

Figure 6. Emergent / canopy strata of Moraella forest (A) and its understory (B). Dipterocarpus zeylanicus, $>1.5 \mathrm{~m}$ in diameter (C), Vateria copallifera (D) and Shorea dyeri (E), the abundant tree species, all belonging to family Dipterocarpaceae. 
could be a contributory factor, among others, for the absence of members of genus Doona and other such species characteristic of forests in SW Sri Lanka. The presence of species such as Chukrasia tabularis A. Juss. and Filicium decipiens (Wight and Arn.) Thw. also suggest that this forest lies at the farthest end of the everwet climate bordering the seasonally dry intermediate zone climate. Although a number of characteristic species that occur in the Moist Mixed Evergreen Forest of Jayasuriya et al. (2006) are also found in this forest, the abundance of dipterocarps in the Moraella forest makes it floristically different from such forests in the Intermediate zone of Sri Lanka. Considering these climatic and floristic data, it could be inferred that Moraella forest and its surrounding region most likely mark the northeastern limit of the distribution of TLRF, but with the absence of any of the Doona species that characterise the lowland rain forests of SW Sri Lanka. One may question whether a change in climate of SW Sri Lanka from an ever wet to a less wet seasonal climate would affect the survival of the Doona species in its TLRF.

The Moraella forest type, possibly, once prevalent in the riverine foot hills of the western and $\mathrm{SW}$ slopes of the KR, is now restricted to a small area. Threats to its conservation even continue to this date. At present, illegal logging of timber trees (Fig. 7), encroachments for tea and spice cultivation and for settlements are among its main threats. Other potential threats include the spread of invasive alien plant species. Clidemia hirta (L.) D. Don, Pinus caribaea Morelet, Acacia sp. and Alstonia macrophylla Wall have invaded the disturbed parts of the forest fragments in Moraella (Fig. 7). These invasive plant species could aggressively interact with the seedling growth of the native species, by shading them out, and/or competing for limited resources such as water during less wet periods, nutrients and space. More recently, a mini hydro power project has also been proposed to be established. If permission is granted, it could pose a negative impact on the biodiversity of this small forest fragment.

In the Moraella forest four critically endangered species, Tolypanthus gardneri (Thw.) Tieghem (Loranthaceae) Bhesa nitidissima Kosterm. (Celastraceae), Chionanthes albidiflora Thw. (Oleaceae) and Glochidion acutifolium Alston (Euphorbiaceae), and five endangered species (Appendix 1) were also recorded by us. The unidentified Dipterocarpus species (suspected to be $D$. insignis) and Shorea dyeri, when found, were only recorded in very small populations in other lowland rain forests in SW Sri Lanka previously sampled by us (Gunatilleke and Gunatilleke 1991); but in Moraella forest they are abundant in the canopy and they have a relatively high population in this habitat. Thus, Moraella forest, though a small isolated fragment surrounded by tea plantations still serves as a refugium for these species and for the 89 endemic species as well (Table 2), highlighting the importance of its conservation. Though the forest fragment close to Kosgama village was not extensively surveyed, its structure and canopy species are similar to Moraella forest. Together they represent a unique forest type, not recorded previously from the KR.

The present study also provides an insight into what native plant species could be selected for reforestation and restoration programs in the neighbouring pine plantations and grasslands in the KR (Fig. 8), as done elsewhere (Ashton et al., 1997).

The failure to recognize a lowland forest type in the KR during previous forest surveys may be because most of the lowland forest formations below $900 \mathrm{~m}$ elevation, particularly on the western and SW foot hills and valleys of the KR (i.e. the wetter parts of the Dumbara Mitiyawatha), had already been converted to cash crop plantations and no large parcels of forests had been detected in aerial photographs worthy of investigation by previous investigators (de Rosayro, 1958). Since the Moraella and other such forest fragments lie outside the contiguous forests in the KFR, they were probably not included in Legg's 1995 survey. Other recent floristic surveys conducted too, had focused on lower and upper montane rain forests in the KR (Jayasuriya et al., 1993; Werner, 2001) possibly for the same reason.

As this forest region $(<900 \mathrm{~m})$ is outside the current protected area of the KFR and hence the Central Highlands World Heritage Site, inclusion of forest fragments of this nature within the conservation area or within its buffer zone would enrich the ecosystem diversity of this globally significant protected area. Remnant forest fragments, like the Moraella forest, can be considered as biodiversity refugia, which have facilitated the survival of native biota, over centuries or millennia, under changing environmental conditions. These refugia may offer many taxa the best chances for survival under anthropogenic climate change (Keppel et al., 2011). Identification of such refugia is also important for conservation as they could serve as catalysts for recolonization of the surrounding non-forest matrix. Recent national level assessments too, have emphasized the need to 
identify biodiversity refugia in the island, located outside the existing protected area network, establish them as corridors and buffer zones and link them to the protected forests to enhance their conservation (Jayasuriya et al., 2006; de Silva. 2007).

As done earlier (Wikramanayake and Gunatilleke, 2002), a plea is made again to establish tree corridors of natural forest species between these vestigial isolated forest fragments as well as the already conserved forest reserve, through a well coordinated restoration programme. The areas that could be restored to bring about this connectivity are outlined in Fig. 8. Restoration would enhance the sustained management of these very small forest fragments, ensuring conservation of the rich genetic diversity in Moraella lowland rain forest in the KR.
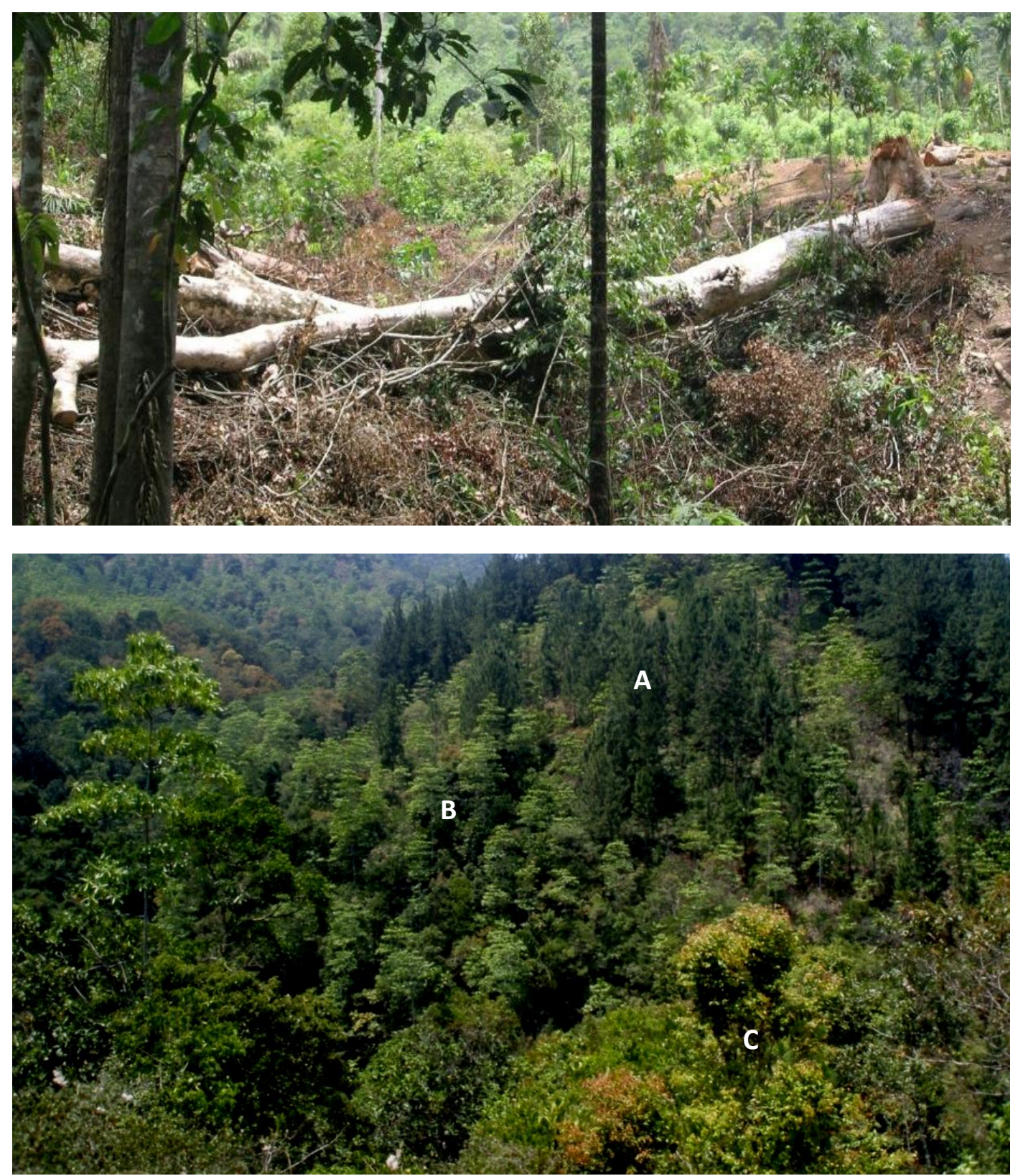

Figure 7. An illegally logged timber tree of Dipterocarpus zeylanicus (upper) and invasive species of Pinus caribaea (A) and Alstonia macrophylla (B) patches in the neighbourhood of the wet lowland rain forest $(\mathrm{C})$ (lower) in Moraella, in the Knuckles Range. 


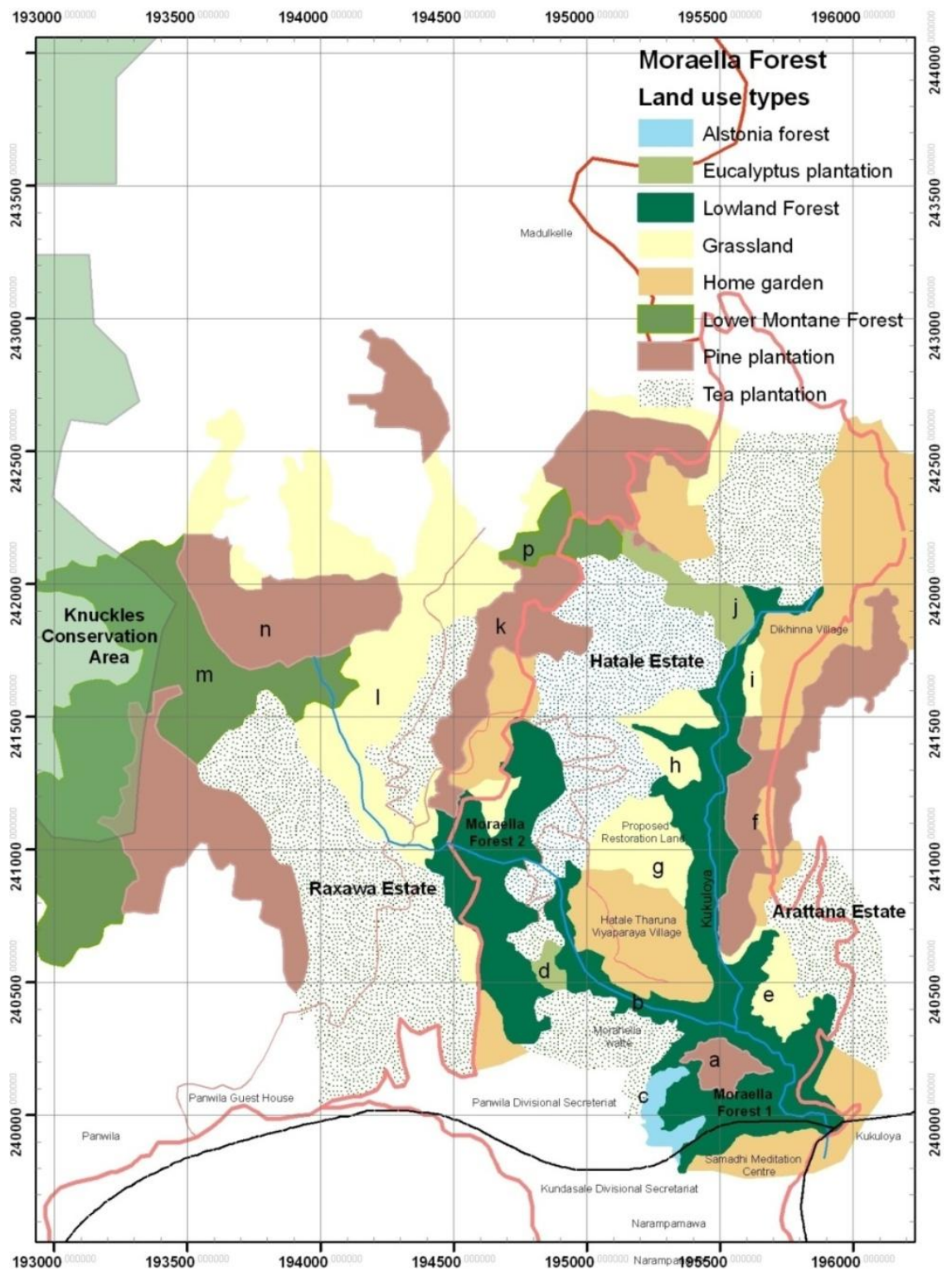

Figure 8. Different land use types around Moraella forest, most of which (Alstonia, Eucalyptus, Pinus stands and grasslands marked as 'a-p') could be used for forest restoration to bring about connectivity (Co-ordinates based on Sri Lanka Datum 1999, National Atlas, 1988).

\section{ACKNOWLEDGEMENTS}

This study was made possible through the financial assistance provided by the Darwin Initiative Project No. 15010 (implemented jointly through the Universities of Peradeniya, Sri Lanka and Aberdeen, UK) and the Asia Pacific Network for Global Change Fund for Collaborative Studies in Tropical Asian Dendrochronology (Grant No. ARCP200717NMY).

\section{REFERENCES}

Abeywickrama, B.A. (1964). The Pteridophytes of the Knuckles region. Ceylon Journal of Science 5: 18-29.

Anon. (1997a). Resource inventories for protected areas-Victoria-Randenigala-Rantembe Sanctuary. Final Unpublished Report prepared for the Department of Wildlife Conservation, Sri Lanka. 293 Pp. \& appendices. 
Anon. (1997b). Designing an optimum protected areas system for Sri Lanka's natural forests. Published by the IUCN/WCMC/FAO for the Forest Department of Sri Lanka.

Anon. (1998). Batadandu Kanduvetiye Urumaya (in Sinhala). Matale District Cultural Fund Publication. $116 \mathrm{Pp}$.

Ashton, P.M.S., Gamage, S., Gunatilleke, I.A.U.N. and Gunatilleke, C.V.S. (1997). Restoration of a Sri Lankan rain forest using Carribean pine (Pinus caribaea) as a nurse for establishing late successional tree species. $J$. App. Ecol. 34: 915925.

Ashton, P.S. (1980). Dipterocarpaceae. In: Dassanayake, M.D. and Fosberg, F.R. (eds.). $A$ Revised Handbook to the Flora of Ceylon, Vol. 1. Amarind Publishing Co. Pvt. Ltd., New Delhi. Pp. 364423.

Ashton, P.S. and Gunatilleke, C.V.S. (1987). New light on the plant geography of Ceylon. Historical plant geography. Journal of Biogeography 14: 249-285.

Bambaradeniya, C.N.B. and Ekanayake, S.P. (2003). A guide to the biodiversity of Knuckles forest region. IUCN - The World Conservation Union, Sri Lanka Country Office, Colombo. 68 Pp.

Cooray, P.G. (1984). An introduction to the geology of Sri Lanka. $2^{\text {nd }}$ revised Ed. National Museums Department, Colombo. 340 Pp.

de Rosayro, R.A. (1950). Ecological conceptions and vegetational types with special reference to Ceylon. The Trop. Agric. (Cey.) 106(3): 108 121.

de Rosayro, R.A. (1958). The climate and vegetation of the Knuckles Region of Ceylon. The Ceylon Forester 3(3 \& 4): 201-260.

de Silva, M. A. T. (ed). (2007). The Addendum to the Biodiversity Conservation in Sri Lanka: A Framework for Action. Biodiversity Secretariat, Ministry of Environment and Natural Resources. $52 \mathrm{Pp}$.

Domros, M. (1974). The agroclimate of Ceylon. Franz Steiner Verlag GMBH.Wiesbaden. 265 Pp.

Ferguson, A.M. (1859). The Ferguson's Ceylon Directory. Summary of Useful Information and
Plantation Gazetteer for 1859.

Greller, A.M. and Balasubramaniam, S. (1993). Physiognomic, floristic and bioclimatological characterization of the major forest types of Sri Lanka. In: Erdelen, W., Preu, C., Ishwaran, N. and Madduma Bandara, C.M. (Eds), Proceedings of the International Symposium on Ecology and Landscape Management in Sri Lanka, Margraf Verlag, Weikersheim. Pp. 55 78.

Gunatilleke, C.V.S. and Gunatilleke, I.A.U.N. (1984). Distribution of endemics in the tree flora of a lowland hill forest in Sri Lanka. Biological Conservation 28: 275285.

Gunatilleke, C.V.S. and Gunatilleke, I.A.U.N. (1991). Threatened woody endemics of the wet lowlands of Sri Lanka and their conservation. Biological Conservation 55:17-36.

Gunatilleke, C.V.S., Gunatilleke, I.A.U.N., Ethugala, A.U.K. and Esufali, S. (2004a). Ecology of Sinharaja Rain Forest and the Forest Dynamics Plot in Sri Lanka's Natural World Heritage Site. WHT Publications (Pvt.) Ltd. 221 Pp.

Gunatilleke, C.V.S., Gunatilleke, I.A.U.N., Ethugala, A.U.K., Weerasekera, N.S., Esufali, S., Ashton, P.S., Ashton, P.M.S. and Wijesundera, D.S.A. (2004b). Community ecology in an ever wet forest in Sri Lanka. In: E.C. Losos and E. G. Leigh, Jr. (Eds). Tropical Forest Diversity and Dynamism: Findings from a Large-Scale Plot Network. The University of Chicago Press. Pp. 119144.

Gunatilleke, C.V.S, Gunatilleke, I.A.U.N., Esufali, S., Harms, K.E., Ashton, P.M.S., Burslem, D.F.R.P. and Ashton, P.S. (2006). Species habitat associations in a Sri Lankan dipterocarp forest. Journal of Tropical Ecology 22: 371384 .

IUCN Red List (2007). The 2007 Red List of Threatened Fauna and Flora of Sri Lanka. IUCN and Ministry of Environment and Natural Resources, Sri Lanka. Colombo. 148 Pp.

Jayasuriya, A.H.M. (1993). Phytosociological studies of mid elevational (lower montane) evergreen forests in-Sri-Lanka. In: Erdelen, W., Preu, C., Ishwaran, N. and Madduma Bandara, C.M. (eds.), Proceedings of the International Symposium on Ecology and Landscape 
Management in Sri Lanka, Margraf Verlag, Weikersheim. Pp. 7994.

Jayasuriya, A.H.M., Kitchener D. and Biradar, C.M. (2006). Portfolio of Strategic Conservation Sites/Protected Area Gap Analysis in Sri Lanka. Unpublished report, Ministry of Environmental and Natural Recourses. Colombo, Sri Lanka. 260 Pp.

Keppel, G., Van-Niel, K.P., Wardell-Johnson, G.W., Yates, C.J., Byrne, M., Mucina, L., Schut, A.G.T., Hopper, S.D. and Franklin, S.E. (2011). Refugia: identifying and understanding safe havens for biodiversity under climate change. Global Ecology and Biogeography (on line version 14 June 2011).

Koelmeyer, K.O. (1958). Climatic classification and the vegetational distribution in Ceylon. The Ceylon Forester 3: 144288.

Kostermans, A.H.J.H., (1992). A Handbook of the Dipterocarpaceae of Sri Lanka. WHT Publications, Colombo. Pp. 243.

Legg, C. (1995). A geographic information system for planning and managing the conservation of tropical forests in the Knuckles range. The Sri Lanka Forester, Special Issue: 2536.

Merritt, V.G. and Ranatunge, M.S. (1959). Aerial photographic survey of Sinharaja forest. The Ceylon Forester 4 (No.2): 103156.
Mueller Dombois, D. (1968). Ecogeographic analysis of a climate map of Ceylon with particular reference to vegetation. The Ceylon Forester 8 (Nos. 3 and 4): 3958.

National Atlas of Sri Lanka. (1988). The National Atlas of Sri Lanka. Survey Department Sri Lanka. $142 \mathrm{Pp}$.

Panabokke, C.R. (1996). Soils and AgroEcological Environments of Sri Lanka. NARESA, Colombo. $220 \mathrm{Pp}$.

Senaratna, L.K. (2001). A Check List of the Flowering Plants of Sri Lanka. National Science Foundation Sri Lanka. 451 Pp.

Sri Barathie, K.P. (1993). Impacts on the Knuckles Range of forests in Sri Lanka. In: Erdelen, W., Preu, C., Ishwaran, N. and Madduma Bandara, C.M. (Eds), Symp. Ecology and Landscape Management in Sri Lanka. Margraf Verlag. Weikersheim. Pp. 237-241.

Werner, W. (2001). Sri Lanka's Magnificient Cloud Forests. WHT Publications, Colombo. 96 Pp.

Wikramanayake E.D. and Gunatilleke S. (2002) Sri Lanka's montane rain forests. In: E.D. Wikramanayake, E. Dinerstein and C.J. Loucks (Eds) Terrestrial ecoregions of the Indo-Pacific: a conservation assessment. Island Press, Washington, DC. Pp. 290-293. 
APPENDIX 1: Plant species recorded in Moraella forest (column 2) and their distribution in forest types within the Knuckles Forest Reserve (KFR) and other lowland rainforests of SW Sri Lanka (KO: Kottawa, HI: Hinidumkanda, KA: Kanneliya, S: Sinharaja, G: Gilimale). The endemic (E), native (N) and introduced (I) status of species, as well as their IUCN threatened status: globally threatened-vulnerable (GVU), critically endangered (GCR) and endangered (GEN) and nationally threatened-vulnerable (NVU), endangered (NEN), critically endangered (NCR), near threatened (NNT) and not threatened (NOT) species.

\begin{tabular}{|c|c|c|c|c|c|c|c|c|c|}
\hline \multirow[t]{2}{*}{ Family } & \multirow[t]{2}{*}{ Species Name } & \multirow[t]{2}{*}{ E/N/I } & \multirow{2}{*}{$\begin{array}{l}\text { Threat } \\
\text { status }\end{array}$} & \multicolumn{6}{|c|}{$\begin{array}{l}\text { Moraella species also found in other } \\
\text { forests in Sri Lanka }\end{array}$} \\
\hline & & & & KO & HI & KA & $\mathbf{S}$ & $\mathbf{G}$ & KFR \\
\hline \multicolumn{10}{|l|}{ Tree species } \\
\hline \multirow[t]{5}{*}{ ANACARDIACEAE } & Mangifera zeylanica & $\mathrm{E}$ & NOT & $*$ & $*$ & $*$ & $*$ & $*$ & $*$ \\
\hline & Nothopegia beddomei & $\mathrm{N}$ & NOT & $*$ & & $*$ & $*$ & $*$ & $*$ \\
\hline & Semecarpus gardneri & $\mathrm{E}$ & NOT & $*$ & $*$ & $*$ & $*$ & $*$ & $*$ \\
\hline & Semecarpus nigro-viridis & $\mathrm{E}$ & NOT & & $*$ & & $*$ & & $*$ \\
\hline & Semecarpus walkeri & $\mathrm{E}$ & NOT & $*$ & $*$ & $*$ & $*$ & $*$ & \\
\hline \multirow[t]{4}{*}{ ANNONACEAE } & Cyathocalyx zeylanica & $\mathrm{N}$ & NOT & $*$ & & & $*$ & $*$ & $*$ \\
\hline & Xylopia championii & $\mathrm{E}$ & NOT & $*$ & & & $*$ & & \\
\hline & Xylopia nigricans & $\mathrm{E}$ & NNT & & & & & & \\
\hline & Xylopia parvifolia & $\mathrm{N}$ & NOT & & & & $*$ & $*$ & \\
\hline \multirow[t]{2}{*}{ APOCYNACEAE } & Alstonia macrophylla & I & NOT & & & $*$ & & $*$ & \\
\hline & Alstonia scholaris & $\mathrm{N}$ & NOT & & & & & $*$ & $*$ \\
\hline \multirow[t]{3}{*}{ ARECACEAE } & Areca catechu & I & NOT & & & & & & \\
\hline & Caryota urens & $\mathrm{N}$ & NOT & & & & & & \\
\hline & Oncosperma fasciculatum & $\mathrm{E}$ & $\mathrm{NVU}$ & & & $*$ & & $*$ & $*$ \\
\hline ASTERACEAE & Vernonia arborea & $\mathrm{N}$ & NOT & & & & & & \\
\hline BIGNONIACEAE & Stereospermum colais & $\mathrm{N}$ & NOT & & & & & & $*$ \\
\hline \multirow[t]{2}{*}{ BOMBCACEAE } & Bombax ceiba & $\mathrm{N}$ & NOT & * & & & $*$ & & \\
\hline & Cullenia ceylanica & $\mathrm{E}$ & GVU & $*$ & $*$ & $*$ & $*$ & $*$ & $*$ \\
\hline BURSERACEAE & Canarium zeylanicum & $\mathrm{E}$ & GVU & $*$ & $*$ & $*$ & $*$ & $*$ & \\
\hline \multirow[t]{2}{*}{ CELASTRACEAE } & Bhesa ceylanica & $\mathrm{E}$ & GVU & $*$ & $*$ & $*$ & $*$ & $*$ & \\
\hline & Bhesa nitidissima & $\mathrm{E}$ & GCR & & & & & & \\
\hline \multirow[t]{8}{*}{ CLUSIACEAE } & Calophyllum moonii & $\mathrm{E}$ & NOT & $*$ & $*$ & $*$ & $*$ & & \\
\hline & Calophyllum trapezifolium & $\mathrm{E}$ & NOT & & & & $*$ & & $*$ \\
\hline & Garcinia hermonii & $\mathrm{E}$ & NOT & * & $*$ & $*$ & $*$ & $*$ & \\
\hline & Garcinia morella & $\mathrm{N}$ & NOT & * & & $*$ & $*$ & $*$ & $*$ \\
\hline & Garcinia quaesita & $\mathrm{E}$ & GVU & $*$ & $*$ & $*$ & $*$ & $*$ & \\
\hline & Garcinia spicata & $\mathrm{N}$ & NOT & & & & $*$ & & \\
\hline & Garcinia thwaitesii & $\mathrm{E}$ & GEN & & & & & & \\
\hline & Mesua ferrea & $\mathrm{E}$ & NOT & $*$ & $*$ & $*$ & $*$ & $*$ & \\
\hline COMBRATACEAE & Terminalia bellirica & $\mathrm{N}$ & NOT & & & & $*$ & $*$ & $*$ \\
\hline \multirow[t]{4}{*}{ DIPTEROCARPACEAE } & Dipterocarpus sp. A & & NOT & & & & & & \\
\hline & Dipterocarpus zeylanicus & $\mathrm{E}$ & NOT & $*$ & $*$ & & $*$ & $*$ & \\
\hline & Shorea dyeri & $\mathrm{E}$ & NVU & & $*$ & $*$ & & $*$ & \\
\hline & Vateria copallifera & $\mathrm{E}$ & NOT & & & $*$ & & $*$ & $*$ \\
\hline
\end{tabular}


Tree species continued.

\begin{tabular}{|c|c|c|c|c|c|c|c|c|c|}
\hline \multirow[t]{2}{*}{ Family } & \multirow[t]{2}{*}{ Species Name } & \multirow[t]{2}{*}{ E/N/I } & \multirow{2}{*}{$\begin{array}{l}\text { Threat } \\
\text { status }\end{array}$} & \multicolumn{6}{|c|}{$\begin{array}{c}\text { Moraella species also found in other } \\
\text { forests in Sri Lanka }\end{array}$} \\
\hline & & & & KO & HI & $\mathbf{K A}$ & $\mathbf{S}$ & $\mathbf{G}$ & KFR \\
\hline \multirow[t]{3}{*}{ EBENACEAE } & Diospyros insignis & $\mathrm{E}$ & NOT & & & $*$ & $*$ & $*$ & \\
\hline & Diospyros racemosa & $\mathrm{N}$ & NVU & & & & $*$ & $*$ & \\
\hline & Diospyros sylvatica & $\mathrm{N}$ & NOT & & & & $*$ & $*$ & * \\
\hline \multirow[t]{3}{*}{ ELAEOCARPACEAE } & Elaeocarpus amoenus & $\mathrm{E}$ & NOT & & & & & & $*$ \\
\hline & Elaeocarpus serratus & $\mathrm{N}$ & NOT & & & & $*$ & $*$ & \\
\hline & Elaeocarpus sp. A & & & & & & & & \\
\hline \multirow[t]{12}{*}{ EUPHORBIACEAE } & Antidesma pyrifolium & $\mathrm{E}$ & NNT & & $*$ & $*$ & $*$ & $*$ & $*$ \\
\hline & Aporusa acuminata & $\mathrm{N}$ & NOT & & & & $*$ & & \\
\hline & Aporusa lanceolata & $\mathrm{E}$ & NOT & & $*$ & $*$ & $*$ & $*$ & \\
\hline & Bridelia moonii & $\mathrm{E}$ & NNT & $*$ & $*$ & $*$ & $*$ & $*$ & \\
\hline & Bridelia retusa & $\mathrm{N}$ & NOT & & & & $*$ & & $*$ \\
\hline & Fahrenheitia zeylanica & $\mathrm{N}$ & NNT & & & & & $*$ & $*$ \\
\hline & Glochidion acutifolium & $\mathrm{E}$ & NCR & & & $*$ & $*$ & & $*$ \\
\hline & Glochidion coriaceum & $\mathrm{E}$ & NNT & & & & $*$ & & \\
\hline & Glochidion stellatum & $\mathrm{E}$ & NOT & & & $*$ & $*$ & $*$ & $*$ \\
\hline & Glochidion zeylanicum & $\mathrm{E}$ & NOT & & & & $*$ & & $*$ \\
\hline & Macaranga indika & $\mathrm{N}$ & NOT & & & & & $*$ & \\
\hline & Mallotus fuscescens & $\mathrm{E}$ & NNT & $*$ & $*$ & $*$ & $*$ & $*$ & \\
\hline FABACEAE & Abarema bigemina & $\mathrm{E}$ & GVU & & & & $*$ & $*$ & \\
\hline \multirow[t]{6}{*}{ FLACOURTIACEAE } & Erythrospermum & $\mathrm{E}$ & NOT & & & & & & \\
\hline & zeylanicum & & & & & & & & \\
\hline & Homalium ceylanicum & $\mathrm{N}$ & NOT & & & $*$ & $*$ & $*$ & * \\
\hline & Osmelia gardneri & $\mathrm{E}$ & NOT & & & & $*$ & $*$ & \\
\hline & Scolopia acuminata & $\mathrm{E}$ & NOT & * & & $*$ & $*$ & $*$ & $*$ \\
\hline & Trichadenia zeylanica & $\mathrm{E}$ & GVU & $*$ & $*$ & $*$ & $*$ & $*$ & \\
\hline HIPPOCRATEACEAE & Loeseneriella arnottiana & $\mathrm{N}$ & NOT & & & & $*$ & & $*$ \\
\hline ICACINACEAE & Gomphandra tetrandra & $\mathrm{N}$ & NOT & & & & $*$ & & \\
\hline \multirow[t]{6}{*}{ LAURACEAE } & Cinnamomum verum & $\mathrm{E}$ & NOT & $*$ & & & $*$ & & \\
\hline & Cryptocarya wightiana & $\mathrm{N}$ & GVU & $*$ & $*$ & $*$ & $*$ & $*$ & $*$ \\
\hline & Litsea longifolia & $\mathrm{E}$ & GVU & & & $*$ & $*$ & $*$ & $*$ \\
\hline & Neolitsea cassia & $\mathrm{E}$ & NOT & & & $*$ & $*$ & $*$ & $*$ \\
\hline & Neolitsea fuscata & $\mathrm{E}$ & NOT & & & & & & $*$ \\
\hline & Persea macrantha & $\mathrm{N}$ & NOT & & & & $*$ & & $*$ \\
\hline LEEACEAE & Leea indica & $\mathrm{N}$ & NOT & $*$ & & $*$ & $*$ & $*$ & $*$ \\
\hline \multirow[t]{2}{*}{ MELASTOMATACEAE } & Memecylon capitellatum & $\mathrm{E}$ & NOT & & & & & $*$ & \\
\hline & Memecylon grande & $\mathrm{E}$ & NOT & & & & $*$ & & \\
\hline \multirow[t]{3}{*}{ MELIACEAE } & Aphanamixis polystachya & $\mathrm{N}$ & NOT & & & & & & \\
\hline & Chukrasia tabularis & $\mathrm{N}$ & NOT & & & & & & $*$ \\
\hline & Walsura trifoliolata & $\mathrm{N}$ & NOT & & & & $*$ & & \\
\hline
\end{tabular}


Tree species continued.

\begin{tabular}{|c|c|c|c|c|c|c|c|c|c|}
\hline \multirow[t]{2}{*}{ Family } & \multirow[t]{2}{*}{ Species Name } & \multirow[t]{2}{*}{$\mathrm{E} / \mathrm{N} / \mathbf{I}$} & \multirow{2}{*}{$\begin{array}{l}\text { Threat } \\
\text { status }\end{array}$} & \multicolumn{6}{|c|}{$\begin{array}{l}\text { Moraella species also found in other } \\
\text { forests in Sri Lanka }\end{array}$} \\
\hline & & & & KO & HI & KA & $\mathbf{S}$ & $\mathbf{G}$ & KFR \\
\hline \multirow[t]{5}{*}{ MORACEAE } & Artocarpus nobilis & $\mathrm{E}$ & GVU & $*$ & $*$ & $*$ & $*$ & $*$ & \\
\hline & Ficus callosa & $\mathrm{N}$ & NOT & & & & $*$ & & $*$ \\
\hline & Ficus microcarpa & $\mathrm{N}$ & NOT & & & & $*$ & & $*$ \\
\hline & Ficus nervosa & $\mathrm{N}$ & NOT & & & & $*$ & $*$ & $*$ \\
\hline & Ficus virens & $\mathrm{N}$ & NOT & & & & & & $*$ \\
\hline \multirow[t]{2}{*}{ MYRISTICACEAE } & Myristica ceylanica & $\mathrm{N}$ & NOT & & & & & & $*$ \\
\hline & Myristica dactyloides & $\mathrm{E}$ & NOT & $*$ & $*$ & $*$ & $*$ & $*$ & $*$ \\
\hline \multirow[t]{13}{*}{ MYRTACEAE } & Cleistocalyx nervosum & $\mathrm{N}$ & NOT & & & & $*$ & $*$ & $*$ \\
\hline & Syzygium aqueum & $\mathrm{N}$ & NOT & & & & $*$ & $*$ & $*$ \\
\hline & Syzygium assimile & $\mathrm{E}$ & NOT & & $*$ & & $*$ & $*$ & $*$ \\
\hline & Syzygium caryophyllatum & $\mathrm{N}$ & NOT & & & & $*$ & & \\
\hline & Syzygium cylindricum & $\mathrm{E}$ & NVU & & & $*$ & $*$ & & \\
\hline & Syzygium gardneri & $\mathrm{N}$ & NOT & & & & $*$ & & $*$ \\
\hline & Syzygium jambos & I & NOT & & & & & & \\
\hline & Syzygium lanceolatum & $\mathrm{N}$ & NVU & & & & & & \\
\hline & Syzygium neesianum & $\mathrm{E}$ & NOT & $*$ & $*$ & $*$ & $*$ & $*$ & $*$ \\
\hline & Syzygium rubicundum & $\mathrm{N}$ & NOT & & & & $*$ & $*$ & $*$ \\
\hline & Syzygium sp. A & & & & & & & & \\
\hline & Syzygium sp. B & & & & & & & & \\
\hline & Syzygium sp. C & & & & & & & & \\
\hline OCHNACEAE & Gomphia serrata & $\mathrm{N}$ & NOT & & & $*$ & $*$ & $*$ & $*$ \\
\hline \multirow[t]{2}{*}{ RHIZOPHORACEAE } & Carallia brachiata & $\mathrm{N}$ & NOT & $*$ & & & $*$ & $*$ & $*$ \\
\hline & Carallia calycina & $\mathrm{E}$ & GVU & & & $*$ & $*$ & $*$ & \\
\hline ROSACEAE & Prunus walkeri & $\mathrm{E}$ & GVU & $*$ & $*$ & $*$ & $*$ & $*$ & $*$ \\
\hline \multirow[t]{7}{*}{ RUBIACEAE } & Aidia gardneri & $\mathrm{E}$ & $\mathrm{NVU}$ & & & $*$ & & $*$ & $*$ \\
\hline & Canthium coromandelicum & $\mathrm{N}$ & NOT & & & & $*$ & & $*$ \\
\hline & Dichilanthe zeylanica & $\mathrm{E}$ & NVU & & & $*$ & $*$ & & \\
\hline & Gaertnera vaginans & $\mathrm{E}$ & NOT & $*$ & & $*$ & & $*$ & \\
\hline & Psilanthus tranvancorensis & $\mathrm{N}$ & NOT & & & & $*$ & & \\
\hline & Psydrax dicoccos & $\mathrm{E}$ & NOT & * & $*$ & $*$ & $*$ & $*$ & $*$ \\
\hline & Wendlandia bicuspidata & $\mathrm{E}$ & NOT & & & & $*$ & & $*$ \\
\hline \multirow[t]{3}{*}{ RUTACEAE } & Acronychia pedunculata & $\mathrm{N}$ & NOT & & & & $*$ & $*$ & $*$ \\
\hline & Melicope lunu-ankenda & $\mathrm{N}$ & NOT & & & & & $*$ & \\
\hline & Micromelum minutum & $\mathrm{E}$ & NOT & & & & & & $*$ \\
\hline \multirow[t]{4}{*}{ SAPINDACEAE } & Dimocarpus longan & $\mathrm{N}$ & NOT & $*$ & & $*$ & $*$ & $*$ & $*$ \\
\hline & Filicium decipiens & $\mathrm{N}$ & NOT & & & & $*$ & $*$ & $*$ \\
\hline & Glenniea unijuga & $\mathrm{E}$ & GVU & & & & $*$ & & \\
\hline & Pometia pinnata & $\mathrm{N}$ & NOT & & & $*$ & $*$ & $*$ & \\
\hline
\end{tabular}


Tree species continued.

\begin{tabular}{|c|c|c|c|c|c|c|c|c|c|}
\hline \multirow[t]{2}{*}{ Family } & \multirow[t]{2}{*}{ Species Name } & \multirow[t]{2}{*}{ E/N/I } & \multirow{2}{*}{$\begin{array}{l}\text { Threat } \\
\text { status }\end{array}$} & \multicolumn{6}{|c|}{$\begin{array}{l}\text { Moraella species also found in other } \\
\text { forests in Sri Lanka }\end{array}$} \\
\hline & & & & KO & HI & $\mathbf{K A}$ & $\mathbf{S}$ & $\mathbf{G}$ & KFR \\
\hline \multirow[t]{4}{*}{ SAPOTACEAE } & Chrysophyllum roxburghii & $\mathrm{N}$ & NOT & & & & $*$ & & \\
\hline & Isonandra lanceolata & $\mathrm{N}$ & NOT & & & $*$ & $*$ & & $*$ \\
\hline & Madhuca moonii & $\mathrm{E}$ & GVU & & & $*$ & & $*$ & \\
\hline & Palaquium grande & $\mathrm{E}$ & GVU & $*$ & & $*$ & $*$ & $*$ & \\
\hline STAPHYLEACEAE & Turpinia malabarica & $\mathrm{N}$ & NOT & & & & $*$ & $*$ & $*$ \\
\hline STERCULIACEAE & Pterospermum suberifolium & $\mathrm{N}$ & NOT & & & $*$ & & & $*$ \\
\hline SYMPLOCACEAE & Symplocos cochinchinensis & $\mathrm{N}$ & NOT & $*$ & & $*$ & $*$ & $*$ & $*$ \\
\hline THEACEAE & Eurya acuminata & $\mathrm{N}$ & NOT & & & & $*$ & & \\
\hline THYMELAEACEAE & Gyrinops walla & $\mathrm{N}$ & NOT & * & & $*$ & $*$ & $*$ & \\
\hline TILIACEAE & Berrya cordifolia & $\mathrm{N}$ & NOT & & & & & & \\
\hline ULMACEAE & Gironniera parvifolia & $\mathrm{N}$ & NOT & & & & $*$ & & \\
\hline \multirow[t]{3}{*}{ VERBENACEAE } & Clerodendrum infortunatum & $\mathrm{N}$ & NOT & & & $*$ & $*$ & $*$ & $*$ \\
\hline & Clerodendrum paniculatum & $\mathrm{N}$ & NOT & & & & & & \\
\hline & Vitex altissima & $\mathrm{N}$ & NOT & & & $*$ & $*$ & $*$ & $*$ \\
\hline \multicolumn{10}{|l|}{ Treelet species } \\
\hline ANNONACEAE & Goniothalamus gardneri & $\mathrm{E}$ & NVU & & & & $*$ & & \\
\hline APOCYNACEAE & Pagiantha dichotoma & $\mathrm{N}$ & NOT & & & & $*$ & $*$ & $*$ \\
\hline CELASTRACEAE & Euonymus walkeri & $\mathrm{E}$ & GVU & & $*$ & $*$ & $*$ & $*$ & $*$ \\
\hline DICHAPETALACEAE & Dichapetalum gelonioides & $\mathrm{N}$ & NOT & $*$ & & $*$ & & $*$ & \\
\hline MORACEAE & Ficus hispida & $\mathrm{N}$ & NOT & & & & $*$ & $*$ & $*$ \\
\hline MYRTACEAE & Eugenia thwaitesii & $\mathrm{N}$ & NOT & & & & $*$ & & $*$ \\
\hline OLACACEAE & Olax zeylanica & $\mathrm{N}$ & NOT & & & & & & \\
\hline OLEACEAE & Chionanthus albidiflora & $\mathrm{E}$ & GCR & & & $*$ & $*$ & & $*$ \\
\hline SYMPLOCACEAE & Symplocos cuneata & $\mathrm{E}$ & NOT & & & $*$ & $*$ & $*$ & \\
\hline \multicolumn{10}{|l|}{ Shrub species } \\
\hline APOCYNACEAE & Rauvolfia sp. A & & NOT & & & & & & \\
\hline ARISTOLOCHIACEAE & Thottea siliquosa & $\mathrm{N}$ & NOT & & & $*$ & $*$ & $*$ & $*$ \\
\hline DRACAENACEAE & Dracaena thwaitesii & $\mathrm{N}$ & NOT & & & & & & \\
\hline \multirow[t]{2}{*}{ EUPHORBIACEAE } & Phyllanthus myrtifolius & $\mathrm{E}$ & NEN & & & & & & $*$ \\
\hline & Sauropus androgynus & $\mathrm{N}$ & NOT & & & & & & \\
\hline MYRSINACEAE & Ardisia gardneri & $\mathrm{E}$ & NOT & $*$ & & $*$ & $*$ & $*$ & $*$ \\
\hline \multirow[t]{6}{*}{ RUBIACEAE } & Lasianthus oliganthus & $\mathrm{E}$ & NVU & & & * & $*$ & $*$ & $*$ \\
\hline & Lasianthus strigosus & $\mathrm{E}$ & NVU & & & & & & $*$ \\
\hline & Lasianthus walkerianus & $\mathrm{E}$ & NOT & & & & $*$ & & \\
\hline & Pavetta indica & $\mathrm{N}$ & NOT & & & & $*$ & $*$ & $*$ \\
\hline & Psychotria gardneri & $\mathrm{E}$ & NVU & & & & $*$ & & $*$ \\
\hline & Psychotria nigra & $\mathrm{E}$ & NOT & $*$ & & $*$ & $*$ & $*$ & $*$ \\
\hline URTICACEAE & Elatostema lineolatum & $\mathrm{E}$ & NOT & & & & & & \\
\hline
\end{tabular}


Shrub species continued.

\begin{tabular}{|c|c|c|c|c|c|c|c|c|c|}
\hline \multirow{2}{*}{ Family } & \multirow{2}{*}{ Species Name } & \multirow[t]{2}{*}{ E/N/I } & \multirow{2}{*}{$\begin{array}{l}\text { Threat } \\
\text { status }\end{array}$} & \multicolumn{6}{|c|}{$\begin{array}{c}\text { Moraella species also found in other } \\
\text { forests in Sri Lanka }\end{array}$} \\
\hline & & & & KO & HI & $\mathbf{K A}$ & $\mathbf{S}$ & $\mathbf{G}$ & KFR \\
\hline VERBENACEAE & Callicarpa tomentosa & $\mathrm{N}$ & NOT & & & & & & $*$ \\
\hline ZINGIBERACEAE & Amomum masticatorium & $\mathrm{E}$ & NOT & & & & & & \\
\hline \multicolumn{10}{|l|}{ Herbaceous species } \\
\hline AMARANTHACEAE & Achyranthes aspera & $\mathrm{N}$ & NOT & & & & & & \\
\hline ASPIENLACEAE & Asplenium bipinnatum & $\mathrm{N}$ & NOT & & & & & & \\
\hline \multirow[t]{3}{*}{ BEGONIACEAE } & Begonia cordifolia & $\mathrm{N}$ & NOT & & & & & & \\
\hline & Begonia dipetala & $\mathrm{N}$ & NOT & & & & & & \\
\hline & Begonia malabarica & $\mathrm{N}$ & NOT & & & & & & \\
\hline \multirow[t]{3}{*}{ COMMELINACEAE } & Commelina benghalensis & $\mathrm{N}$ & NOT & & & & & & \\
\hline & Commelina diffusa & $\mathrm{N}$ & NOT & & & & & & \\
\hline & Murdannia loriformis & $\mathrm{N}$ & NOT & & & & & & \\
\hline CONVOLVULACEAE & Evolvulus alsinoides & $\mathrm{N}$ & NOT & & & & & & \\
\hline CYPERACEAE & Carex filicina & $\mathrm{E}$ & NOT & & & & & & \\
\hline GESNERIACEAE & Chirita zeylanica & $\mathrm{E}$ & NOT & & & & & & \\
\hline \multirow[t]{2}{*}{ LENTIBULARIACEAE } & Utricularia moniliformis & $\mathrm{E}$ & NOT & & & & & & \\
\hline & Utricularia striatula & $\mathrm{N}$ & NOT & & & & & & \\
\hline \multirow[t]{5}{*}{ ORCHIDACEAE } & Acanthephippium bicolor & $\mathrm{N}$ & NEN & & & & & & \\
\hline & Aphyllorchis montana & $\mathrm{N}$ & NVU & & & & & & \\
\hline & Cymbidium ensifolium & $\mathrm{N}$ & NVU & & & & & & \\
\hline & Malaxis versicolor & $\mathrm{N}$ & NOT & & & & & & \\
\hline & Zeuxine regia & $\mathrm{E}$ & NOT & & & & & & \\
\hline PIPERACEAE & Peperomia & $\mathrm{N}$ & NOT & & & & & & \\
\hline & pseudorhombea & & & & & & & & \\
\hline \multirow[t]{2}{*}{ RUBIACEAE } & Acranthera ceylanica & $\mathrm{E}$ & NVU & & & & & & \\
\hline & Psychotria sarmentosa & $\mathrm{N}$ & NOT & & & & & & \\
\hline \multicolumn{10}{|l|}{ Grass species } \\
\hline POACEAE & Coix lacryma-jobi & $\mathrm{N}$ & NOT & & & & & & \\
\hline \multicolumn{10}{|l|}{ Epiphytic species } \\
\hline \multirow[t]{4}{*}{ LORANTHACEAE } & Dendrophthoe & $\mathrm{N}$ & NOT & & & & & & \\
\hline & neelgherrensis & & & & & & & & \\
\hline & Macrosolen capitellatus & $\mathrm{N}$ & NOT & & & & & & \\
\hline & Tolypanthus gardneri & $\mathrm{E}$ & NCR & & & & & & \\
\hline \multirow[t]{6}{*}{ ORCHIDACEAE } & Acampe ochracea & $\mathrm{N}$ & NOT & & & & & & \\
\hline & Bulbophyllum crassifolium & $\mathrm{E}$ & NEN & & & & & & \\
\hline & Cymbidium bicolor & $\mathrm{N}$ & NOT & & & & & & \\
\hline & Dendrobium aphyllum & $\mathrm{N}$ & NOT & & & & & & \\
\hline & Eria lindleyi & $\mathrm{E}$ & NOT & & & & & & \\
\hline & Eria thwaitesii & $\mathrm{E}$ & NEN & & & & & & \\
\hline
\end{tabular}


Epiphytic species continued.

\begin{tabular}{|c|c|c|c|}
\hline Family & Species Name & E/N/I & $\begin{array}{l}\text { Threat } \\
\text { status }\end{array}$ \\
\hline & Luisia zeylanica & $\mathrm{N}$ & NOT \\
\hline & Pholidota pallida & $\mathrm{N}$ & NOT \\
\hline & Polystachya concreta & $\mathrm{N}$ & NOT \\
\hline & Schoenorchis nivea & $\mathrm{E}$ & NOT \\
\hline & Sirhookera lanceolata & $\mathrm{N}$ & NOT \\
\hline & Thrixspermum pulchellum & $\mathrm{E}$ & NOT \\
\hline \multicolumn{4}{|l|}{ Climber species } \\
\hline ARACEAE & Pothos hookeri & $\mathrm{E}$ & NNT \\
\hline ARECACEAE & $\begin{array}{l}\text { Pothos remotiflorus } \\
\text { Calamus zeylanicum }\end{array}$ & $\begin{array}{l}\mathrm{E} \\
\mathrm{E}\end{array}$ & $\begin{array}{l}\text { NVU } \\
\text { NOT }\end{array}$ \\
\hline ASCLEPIADACEAE & Hoya ovalifolia & $\mathrm{N}$ & NOT \\
\hline ASPARAGACEAE & Asparagus sp. A & & NOT \\
\hline COMMELINACEAE & Cyanotis ceylanica & $\mathrm{E}$ & NOT \\
\hline $\begin{array}{l}\text { CONNARACEAE } \\
\text { DIOSCOREACEAE }\end{array}$ & $\begin{array}{l}\text { Connarus championii } \\
\text { Dioscorea spicata }\end{array}$ & $\begin{array}{l}\mathrm{E} \\
\mathrm{N}\end{array}$ & $\begin{array}{l}\text { NOT } \\
\text { NOT }\end{array}$ \\
\hline FABACEAE & Dalbergia pseudosissoo & $\mathrm{N}$ & NOT \\
\hline HIPPOCRATEACEAE & Salacia reticulata & $\mathrm{N}$ & NOT \\
\hline LOGANIACEAE & Fagraea ceilanica & $\mathrm{N}$ & NOT \\
\hline \multirow[t]{2}{*}{ MORACEAE } & Ficus diversiformis & $\mathrm{E}$ & NOT \\
\hline & Ficus laevis & $\mathrm{N}$ & NOT \\
\hline PANDANACEAE & Freycinetia pycnophylla & $\mathrm{E}$ & NOT \\
\hline \multirow[t]{3}{*}{ PIPERACEAE } & Peperomia tetraphylla & $\mathrm{N}$ & NOT \\
\hline & Piper hymenophyllum & $\mathrm{N}$ & NOT \\
\hline & Piper sylvestre & $\mathrm{N}$ & NOT \\
\hline RHAMNACEAE & Ziziphus napeca & $\mathrm{E}$ & NOT \\
\hline VITACEAE & Cissus trilobata & $\mathrm{N}$ & NOT \\
\hline
\end{tabular}

